\title{
Vocalizations as a conservation tool: an auditory survey of the Andean titi monkey Callicebus oenanthe Thomas, 1924 (Mammalia: Primates: Pitheciidae) at Tarangue, Northern Peru
}

\author{
Brooke Catherine Aldrich ${ }^{1}$, Lucy Molleson ${ }^{2}$, K.A.I. Nekaris ${ }^{1}$ \\ ${ }^{1}$ School of Social Sciences and Law, Department of Anthropology and Geography, Oxford Brookes University, \\ Oxford, OX3 OBP, United Kingdom, spidersflies@yahoo.com (corresponding author) \\ ${ }^{2}$ Humboldt, Bristol Marina, Hanover Place, Bristol, BS1 6UH, United Kingdom
}

Key words: crypsis, triangulation, primates, tropical Andes, song

\begin{abstract}
Titi monkeys (Callicebus), morphologically cryptic primates, have been difficult to survey using traditional sighting-based line transect methods. Callicebus-species regularly engage in loud, ritualized singing bouts, which could allow for the use of alternate, potentially more accurate call-based survey methods to monitor populations. The Andean titi monkey, C. oenanthe, is endemic to a small region of northern Peru, an area subject to widespread and rapid deforestation and human colonization. We conducted a call-based survey of $C$. oenanthe at Tarangue, a 74 ha private reserve near Moyobamba. Triangulation of calls was used to map groups of titi monkeys on and around the reserve. 73 mapped calls were used to estimate the presence of between three and six groups per listening area - a total of 23 groups entirely or partially within the borders of Tarangue, yielding an estimated population density of 1.41 individuals per ha. Observations were much greater than those resulting from a visuallybased survey conducted at Tarangue three years earlier. These higher estimates are probably not only due to this more suitable survey method; incessant destruction of habitat occurring in the area surrounding Tarangue may have caused the reserve to become a refuge for displaced individuals, with diminished opportunities for dispersal and establishment of new territories. Immediate measures to prevent further fragmentation within the Andean titi monkey's geographic range are essential in order to allow the species to persist. We recommend the use of triangulation of calls for future surveys of titi monkeys.
\end{abstract}

\section{Contents}

Introduction
Methods . .
Study site
Survey design
Data collection
Data analysis
Results
Acknow
References

\section{Introduction}

Point counts, strip and line transect methods are commonly used to estimate densities of mammal populations (Brockelman and Srikosamatara, 1993; Greenwood, 1996). For visually cryptic species, many of which have special conservation needs (e.g. Nekaris and Jaffe, 2007), the assumptions associated with such methods may be problematic (Duckworth, 1998; McDonald, 2004; Nekaris et al., 2008), partially because most encounters may be auditory only (Davies, 2002). For visually cryptic and/or vocal species, auditory survey methods may be more useful than visual methods - particularly for those species which tend to vocalise consistently at specific times of day or in predictable circumstances. Traditionally used for birds (e.g. European bitterns, Gilbert et al., 1994; corncrakes, Peake and McGregor, 2001), such methods are becoming more common for primates, including Dian's tarsiers (Merker et al., 2005), howler monkeys (Estrada et al., 2002; Estrada et al., 2003), and gibbons (Brockelman and Srikosamatara, 1993; Tallents et al., 2001; Buckley et al., 2006; Geissmann and Nijman, 2006).

Titi monkeys (Callicebus) are small arboreal primates native to South America. Behaviourally cryptic, they hide when threatened, which may have resulted in low density estimates in previous surveys (Kinzey, 1997; Moynihan, 1976). They do, however, engage in daily ritualized bouts of song that probably function to define and reinforce strict territorial boundaries (Kinzey, 1981; Robinson, 1981; Kinzey and Robinson, 1983; Robinson et al., 1987). This high audibility could be used to survey populations that are difficult to locate visually (c.f. Dallmann and Geissmann, 2001).

The Andean titi monkey C. oenanthe Thomas, 1924, is classified as Vulnerable, although extreme habitat loss in its restricted range suggests it is better classified as Critically Endangered (Mark, 2003; Rowe and 
Martinez, 2003; Rylands, 2003; deLuycker, 2006). The known range of $C$. oenanthe appears to be based entirely upon six specimens collected in three locations (Aquino and Encarnacion, 1994, van Roosmalen et al., 2002). It is limited to the upper Rio Mayo valley in northern Peru, between 750 and $950 \mathrm{~m}$ (van Roosmalen et al., 2002). Researchers currently in the field may have found that the Andean titi monkey's range is larger than had been previously recognized (Bóveda Penalba, pers. comm.).

In two previous visual-based surveys at several sites within their range, $C$. oenanthe was either only detected auditorily (Rowe and Martinez, 2003), or was heard more frequently than seen (Mark, 2003). The only other study of this species was on the behaviour and ecology of a single group in an isolated forest fragment (deLuycker, 2006). Rowe and Martinez, Mark and deLuycker all mention the urgent need for further survey work and conservation action.

We conducted a survey of $C$. oenanthe at a private reserve near Moyobamba in northern Peru. Vocalizations were used to estimate the number of groups present at the study site. We discuss the advantages of using this survey method, and the implications of our results for this population of Andean titi monkeys. We reiterate the urgent need for conservation action in the Alto Mayo region.

\section{Methods}

\section{Study site}

Data were collected between May and August, 2006 at Tarangue (southernmost point: 5'58'54.4'S $76^{\circ} 59^{\prime}$ ' 37.6 "W), a reserve owned and protected by Peruvian/ French conservation organization Ikamaperou. Located $8 \mathrm{~km} \mathrm{NNE}$ of the city of Moyobamba, Tarangue ranges in elevation from $800-850 \mathrm{~m}$ asl. Approximately $20 \%$ of Tarangue's 74 ha is cleared of forest. The remaining area consists of secondary growth in various successional stages, ranging from tall, 'old' secondary forest $(>50$ years old, in places incorporating remnants of primary growth) to shambupale (unproductive, fern-covered areas), and includes a large, seasonally-flooded stand of caña brava (Gynerium spp.) and scattered remnant plantations of cacao and citrus trees. Apart from one isolated 1.5 ha fragment, the forested area at Tarangue is continuous. Crop fields and pastures surround the reserve, as do several fragments of tall secondary forest. Deforestation around Tarangue is extensive and continues persistently. During the study period, much of the surrounding area (and part of the reserve itself) was visibly transformed by aggressive and sometimes illegal clearing and burning.

Tarangue is in Peru's Alto Mayo region where the average annual precipitation is between 1500-1700 mm (Börner, 2000, CONDESAN, 2006), with a rainier season from October to March, and a drier season during June to August. The average annual temperature is from $21-23^{\circ} \mathrm{C}$ (Börner, 2000; CONDESAN, 2006; deLuycker, 2006).

\section{Survey design}

Brockelman and Ali's (1987) survey method, in which calling groups are mapped by triangulation, was adapted for use at Tarangue. "Bad weather days" were defined and excluded from the study, although data were experimentally collected on one day of heavy rain. As expected, no calls were heard. Data from this day were not included in the final analysis.

The boundaries of Tarangue were roughly mapped using a Garmin GPSmap 60 unit and blank map grids. The site was divided into five listening areas, determined by the boundaries of the reserve, calculated to cover as much area as possible, while remaining small enough to ensure audibility of all singing groups within that area's boundaries. Each listening area consisted of three named listening points located between 183-305 $\mathrm{m}$ apart. Such spacing ensured audibility of all groups within the boundaries created by those points and within at least a $200 \mathrm{~m}$ radius of each listening point, as the loud calls of male titi monkeys can be heard up to $500 \mathrm{~m}$ away, with a 'critical distance' of about $250 \mathrm{~m}$ (Robinson, 1981). Five day sampling periods were allotted for each listening area, which allowed us to derive the percentage of groups expected to sing within a given number of days, based upon known singing frequencies (Brockelman and Ali, 1987):

$\hat{p}(m)=1-[1-p(1)]^{m}$ where $p=$ the proportion of groups expected to sing in (m) days.

Singing frequency was not available for $C$. oenanthe at Tarangue, and practical constraints precluded the collection of this information. We thus conservatively used $66 \%$ - the lowest singing frequency published for nonisolated groups of Callicebus - to calculate the required sampling period (Kinzey et al., 1977). 


\section{Data collection}

Listening areas were manned by one researcher per listening point for five days, consecutively where possible. Callicebus at Tarangue were never heard to call before $06.30 \mathrm{am}$. Therefore, data were collected from 06.30 am until 09.30 am or until the last audible group finished calling. At each listening point, location and date were noted and for every audible $\mathrm{Cal}$ licebus call, the following information was logged: time call began and ended; compass bearing to the location from which the call was first and last audible; number of individuals or groups calling at that location; distance to calling individual, group or groups. Whenever sightings occurred, researchers noted group size and age/sex composition. Data on atmospheric variables and anthropogenic disturbance were collected daily.

\section{Data analysis}

The geographical coordinates of each triangulated call (defined as those calls heard by two or more researchers simultaneously, whose bearings met when drawn on the map) and sighting were mapped using Garmin MapSource 6.0. Groups were delineated using spatial and temporal data obtained in the field; for example, if two groups were heard singing simultaneously, then it was known that the triangulated points resulting from those calls represented separate groups.

Previous surveys following Brockelman and Ali's methodology have generally been conducted on a much larger spatial scale than the present study (Brockelman and Ali, 1987; Buckley et al., 2006; Geissmann and Nijman, 2006; Tallents et al., 2001). Because this was an intensive survey in a small study area, it was possible to 'cover' the area completely, thus eliminating the need to extrapolate information about density from the sampled area to the whole study area. This meant, however, that audibility of groups from different listening areas overlapped. The delineation of core mapping areas, although resulting in the loss of some data, should have cost only duplicated data, as probability of all groups present within each listening area singing at least once had been maximized by the use of five day sampling periods.

Mean group size was calculated based upon all logged sightings in which group size was estimable. Garmin MapSource 6.0 was used to estimate the amount of forested area within each listening area, and population densities were calculated. As the listening areas were unequal in size, the weighted mean was used to increase accuracy (Greenwood, 1996).

\section{Results}

We mapped 132 calls and recorded groups 33 times visually. An estimated $85 \%$ of individuals calling were not observed visually. Of the 132 calls, 59 fell outside the boundaries of the listening area under study and were excluded from analysis. Thus 73 mapped calls were used to estimate the presence of between three and six groups per listening area. A total of 23 groups of $C$. oenanthe totally or partially within the borders of Tarangue. Additionally, at least four groups were mapped entirely outside the reserve on neighbouring land to the north-west, and two groups were located in patches of forest beyond pastureland to the south of the reserve. Thus the combined total in the study area was at least 29 groups.

The majority of mapped groups were concentrated in the northern half of the reserve. Only seven mapped groups $(30 \%)$ called from within $150 \mathrm{~m}$ of the river. Discounting the approximately $20 \%$ of non-forested area on the reserve, the estimated population density of $C$. oenanthe at Tarangue is 0.38 groups, or 1.40 individuals per ha. Group size could be confidently discerned in 29 of the 33 recorded sightings (Fig. 1), yielding a mean group size of $3.62( \pm \mathrm{SD} 1.91) .62 .0 \%$ of observed groups contained 2-4 individuals. Four of the observed 'groups' were lone titis, and six of the groups consisted of six or more individuals, with a maximum of eight individuals.

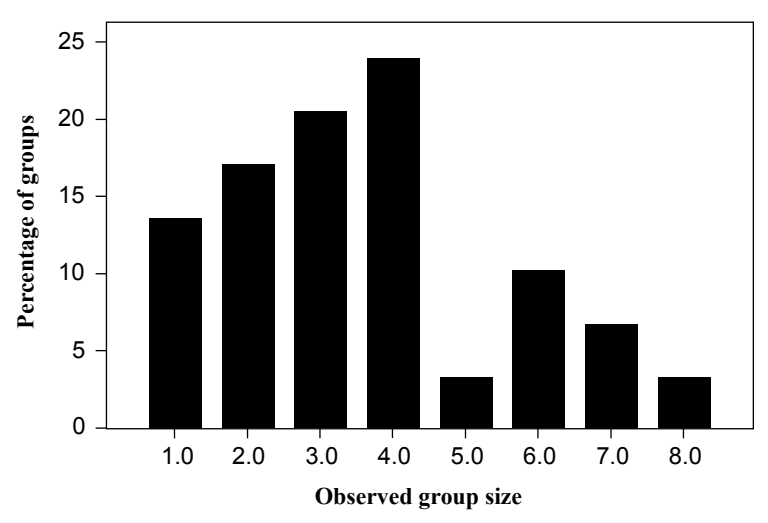

Fig. 1. Number of individuals in groups at Tarangue, showing the prevalence of groups with 3-4 individuals $(n=33)$. 


\section{Discussion}

Similarities in the behaviour and social organization of gibbons and titi monkeys means that the triangulation survey method, based upon morning vocalizations, is applicable for use with Callicebus species with little adaptation necessary (Brockelman and Ali, 1987, Brockelman and Srikosamatara, 1993). The assumptions that this method requires in order to be accurate were not perfectly met in the present study, as singing frequency is not known for $C$. oenanthe. However, we feel that the small size of the study area, combined with information about the behaviour of other closely-related Callicebus species, compensated for this lack of information to an acceptable degree. Further, the assumptions that are not met in this study could be met, given a longer study period - while problems meeting the assumptions for visually based survey methods may be more difficult to overcome (Brockelman and Ali, 1987, Karanth et al., 2004). Given that $85 \%$ of encounters during the present study were purely auditory, and that it was often impossible to see an animal even when it clearly very close by, the titi monkeys in our study could not be surveyed by line transects as this necessitates the animals to be seen on the transect line.

Mark (2003) working in the same area in 2003 estimated numbers based on visual encounters only, found 13 groups in and around the reserve. In contrast to Mark's (2003) study in which the majority of individuals were recorded within $20 \mathrm{~m}$ of rivers or streams, only $30 \%$ of groups recorded in our survey called from within $150 \mathrm{~m}$ of the river. Our study furthermore detected a population three times larger than estimated by Mark (2003) three years earlier. During the interval between the two studies the reserve expanded by some $40 \%$, but there is a discrepancy between the two popu- lation estimates. This may be partially explained by an influx of displaced titis from surrounding areas in response to habitat destruction, but different methodologies certainly contribute to the discrepancy.

Twenty-three groups of $C$. oenanthe are estimated to occur entirely or partially within Tarangue's forested area, with an estimated density of 1.41 individuals / ha, or $141 / \mathrm{km}^{2}$. This estimate is considerably higher than the norm for Callicebus species (Robinson et al., 1987), and is exceeded only by Mason's (1968) estimated $400+C$. cupreus $/ \mathrm{km}^{2}$. Population densities from other studies are summarised in Table 1; the mean population density for Callicebus is $79.4( \pm 126.9$, range 17-400) individuals $/ \mathrm{km}^{2}$, meaning our density estimate is still much higher on average, even when Mason's very high estimate is included. When his estimate is excluded, the mean population density is only 39.3 ( \pm 43.5$)$, or a median of 20 individuals $/ \mathrm{km}^{2}$.

It is likely that, in light of the continuous destruction of habitat in areas surrounding the reserve, Tarangue serves as a refuge for groups of displaced $C$. oenanthe (cf. Defler, 2004). As deforestation advances, and the reserve becomes increasingly isolated from other fragments of forest, opportunity for dispersal to unoccupied territory and the establishment of new territories will decrease (Turner, 1996). These factors could result in unsustainably high population densities within the reserve (cf. Bowers and Matter, 1997; Debinski and Holt, 2000; Onderdonk and Chapman, 2000; Laurance et al., 2002).

Titi monkeys often seem to thrive in moderately disturbed areas or secondary forest (Peres, 1993; Ferrari et al., 2000; van Roosmalen et al., 2002). Callicebus moloch and C. cupreus are frequently found in both natural and man-made edge habitats, and close to areas inhabited by humans (van Roosmalen et al., 2002). But the long-term effect of widespread habitat

Table 1. Abundance estimates of Callicebus in previous studies, showing method used to obtain the estimate.

\begin{tabular}{lllll}
\hline Species & Common name & Estimate & Method & Reference \\
\hline Callibecus moloch & Dusky titi & $400 / \mathrm{km}^{2}$ & $\begin{array}{l}\text { Extrapolation from home } \\
\text { ranges in small forest patches }\end{array}$ & Mason, 1968 \\
& & Line transects & Robinson, 1987 \\
& & Line transects & Wright, 1985 \\
& & Line transects & Stallings, 1984 \\
\hline C. torquatus & Widow titi & $17 / \mathrm{km}^{2}$ & Line transects & Defler, 2004 \\
& & $32 / \mathrm{km}^{2}$ & Line transects & Kinzey, 1981 \\
\hline C. cupreus & Coppery titi & $16 / \mathrm{km}^{2}$ & Line transects & Bennett et al., 2001 \\
\hline C. personatus & Masked titi & $17 / \mathrm{km}^{2}$ & Line transects & Müller, 1996 \\
\hline C. oenanthe & Andean titi & $113 / \mathrm{km}^{2}$ & Vocal survey & this study \\
\hline
\end{tabular}


disturbance and occupation of secondary habitat on Callicebus species is unknown. The apparent preference of some titi monkeys for disturbed forest may indicate the suitability of such habitats, or the genus' adaptability to less than optimal conditions in response to increased competition for resources elsewhere. Although frugivores, many species of titi monkey include large proportions of leaves in their diet (CrandlemireSacco, 1988; Heiduck, 1997; Kinzey, 1997), perhaps placing them at an advantage in disturbed forest as the leaves of edge vegetation contain proportionally more protein (Onderdonk and Chapman, 2000). Despite their ability to utilize disturbed habitats, the titi monkeys at Tarangue still face cumulative pressures resulting from fragmentation and increased anthropogenic disturbance (Laurance et al., 2000, 2002), decreased gene flow, and inbreeding depression (Haipeng et al., 2003).

We have demonstrated that titi monkeys can be effectively surveyed using auditory methods and that this is a more suitable method for monitoring populations than more traditional census techniques. Auditory surveys have been demonstrated as effective conservation tools for monitoring some of the larger species of primates (gibbons - Buckley et al., 2006; Nijman, 2006; Tallents et al., 2001; howler monkeys - Estrada et al., 2002, 2003) to which we may add the smaller-bodied titi monkeys. Despite us finding a significantly larger population of $C$. oenanthe in the Tarangue reserve than previously reported (by extension raising the possibilities that other similar populations are larger as well) continued forest destruction in the Alta Mayo results in an ever-decreasing distribution range of the species. We urge other researchers working in Alta Mayo, as well as researchers working on other Callicebus species throughout South America to adopt auditory survey techniques as to increase our understanding of the real abundances of these cryptic species.

\section{Acknowledgements}

We gratefully acknowledge the following individuals for their advice and academic support: V.A. Atnipp Cross, A. deLuycker, IdeaWild, J. Karlsson, A. Maldonado, S.L. McFadden, A. Oliva Huaman, G. Rios Rodriguez, N. and S. Shanee, B. Smith and family, P. Zapata Celis, Athos, H. Collongues de Palomino, C. Palomino, S. Bearder, T. Aldrich, P. Aldrich and K. Heald. The helpful comments of three reviewers greatly improved the quality of this manuscript. This research was conducted as part of Aldrich's MSc in Primate Conservation at Oxford Brookes Uni- versity and was made possible through the financial support of Primate Conservation, Inc. (USA), the Monkey Sanctuary Trust (UK), Stichting Aap (The Netherlands) and the logistical support of Ikamaperou.

\section{References}

Aquino R, Encarnacion F. 1994. Primates of Peru. Primate Report 40: 6-107.

Bennett CL, Leonard S, Carter S. 2001. Abundance, diversity, and patterns of distrubution of primates on the Tapiche River in Amazonian Peru. American Journal of Primatology 54: 119-126.

Bowers MA, Matter SF. 1997. Landscape ecology of mammals: relationships between density and patch size. Journal of Mammalogy 78: 999-1013.

Brockelman WY, Ali R. 1987. Methods of surveying and sampling forest primate populations. In: Marsh CW and Mittermeier RA, eds. Primate conservation in the Tropical Rain Forest. New York: Alan R. Liss, Inc., 23-62.

Brockelman WY, Srikosamatara S. 1993. Estimation of density of gibbon groups by use of loud songs. American Journal of Primatology 29: 909-923.

Buckland ST, Anderson DR, Burnham KP, Laake JL, Borchers DL, Thomas L. 2001. Introduction to Distance Sampling. Oxford: Oxford University Press.

Buckley C, Nekaris KAI, Husson SJ. 2006. Survey of Hylobates agilis albibarbis in a logged-peat swamp forest: Sabangau catchment, central Kalimantan. Primates 47: $327-$ 335.

Crandlemire-Sacco J. 1988. An ecological comparison of two sympatric primates: Saguinus fuscicollis and Callicebis moloch of Amazonian Peru. Primates 29: 465-475.

Dallmann R, Geissmann T. 2001. Individuality in the female songs of wild silvery gibbons on Java, Indonesia. Contributions to Zoology 70: 41-50.

Debinski DM, Holt RD. 2000. A survey and overview of habitat fragmentation experiments. Conservation Biology 14: 342355 .

Defler TR. 2004. Primates of Colombia. Bogotá: Conservation International.

de Luycker A. 2006. Preliminary report and conservation status of the Rio Mayo titi monkey, Callicebus oenanthe Thomas, 1924, in the Alto Mayo Valley, Northeastern Peru. Primate Conservation 21: 33-39.

Duckworth JW. 1998. The difficulty of estimating population densities of nocturnal forest mammals from line transect counts. Journal of Zoology 246: 466-468.

Estrada A, Castellanos L, Garcia Y, Franco B, Munoz D, Ibarra A, Rivera A, Fuentes E, Jiminez C. 2002. Survey of the black howler monkey, Alouatta pigra, population at the Mayan site of Palenque, Chiapas, Mexico. Primates 43: 51-58.

Estrada A, Luecke L, Van Belle S, Barrueta E, Rosales Meda, M. 2003. Survey of black howler (Alouatta pigra) and spider (Ateles geoffroyi) monkeys in the Mayan sites of Calakmul and Yaxchilán, Mexico and Tikal, Guatemala. Primates 45: 33-39. 
Ferrari SF, Iwanaga S, Messias MR, Ramos EM, Ramos PCS, daCruz Neto EH, Coutinho PEG. 2000. Titi monkeys (Callicebus spp., Atelidae: Platyrrhini) in the Brazilian state of Rondônia. Primates 41: 229-234.

Geissmann T, Nijman V. 2006. Calling in wild silvery gibbons (Hylobates moloch) in Java (Indonesia): behavior, phylogeny and conservation. American Journal of Primatology. 68: 119.

Gilbert G, McGregor P, Tyler G. 1994. Vocal individuality as a census tool: practical considerations illustrated by a study of two rare species. Journal of Field Ornithology. 65: 335-348.

Greenwood JJD. 1996. Basic techniques. In: Sutherland WJ, ed. Ecological census techniques.Cambridge: Cambridge University Press, 11-110.

Haipeng L, Shi-jei M, Zheng-ming M, Yun-xin F, Ya-ping Z. 2003. Genetic diversity and population history of golden monkeys (Rhinopithecus roxellana). Genetics 164: 269-275.

Heiduck S. 1997. Food choice in masked titi monkeys Callicebus personatus melanochir): selectivity or opportunism? International Journal of Primatology 18: 487-502.

Karanth KU, Nichols JD, Samba Kumar N. 2004. Photographic sampling of elusive mammals in tropical forests. In: Thompson, WL, ed. Sampling rare or elusive species. Covelo, Washington: Island Press, 229-247.

Kinzey WG. 1981. The titi monkeys, Genus Callicebus. In: Coimbra-Filho, AF and Mittermeier, RA, ed. Ecology and Behavior of Neotropical Primates. Rio de Janiero: Academia Brasiliera de Ciencias.

Kinzey WG. 1997. New World primates: ecology, evolution and behavior. Hawthorne, New York: Aldine de Gruyter.

Kinzey WG, Robinson, JG. 1983. Intergroup loud calls, range size, and spacing in Callicebus torquatus. American Journal of Physical Anthropology 60: 539-544.

Kinzey WG, Rosenberger AL, Heisler PS, Prowse DL, Trilling JS. 1977. A preliminary field investigation of the yellow handed titi monkey, Callicebus torquatus torquatus, in northern Peru Primates 18: 159-181.

Laurance WF, Lovejoy TE, Vasconcelos HL, Bruna EM, Didham RK, Stouffer PC, Gascon C, Bierregaard RO, Laurance SG, Sampaio E. 2002. Ecosystem decay of Amazonian forest fragments: a 22-year investigation. Conservation Biology 16: 605-618.

Laurance WF, Vasconcelos HL, Lovejoy TE. 2000. Forest loss and fragmentation in the Amazon: implications for wildlife conservation. Oryx 34: 39-45.

Mark MM. 2003. Some observations on Callicebus oenanthe in the Upper Rio Mayo Valley, Peru. Neotropical Primates 11: 183-187.

Mason WA. 1968. Use of space by Callicebus groups. In: Jay PC, ed. Primates: studies in adaptation and variability. New York: Holt, Rinehart and Winston, 200-216.

McDonald LL. 2004. Sampling rare populations. In: Thompson WL, ed. Sampling rare or elusive species. Covelo, Washington: Island Press, 11-42.
Merker S, Yustian I, Mühlenberg M. 2005. Responding to forest degradation: altered habitat use by Dian's tarsier Tarsius dianae in Sulawesi, Indonesia. Oryx 39: 189-195.

Moynihan M. 1976. The New World primates. Princeton, New Jersey: Princeton University Press.

Müller K-H. 1996. Ranging in masked titi monkeys (Callicebus personatus) in Brazil. Folia Primatologica 65: 224-228.

Nekaris KAI, Jaffe S. 2007. Unexpected diversity of slow lorises (Nycticebus spp.) within the Javan pet trade: implications for slow loris taxonomy. Contributions to Zoology 76: 187196.

Nekaris KAI, Blackham GV, Nijman V. 2008. Implications of low encounter rates in five nocturnal species (Nycticebus spp). Biodiversity and Conservation DOI 10.1007/s10531007-9308-X.

Nijman V. 2006. In-Situ and ex-Situ status of the Javan gibbon and the role of zoos in conservation of the species. Contributions to Zoology 75: 161-168.

Onderdonk D, Chapman CA. 2000. Coping with forest fragmentation: the primates of Kibale National Park, Uganda. International Journal of Primatology 21: 587-611.

Peake TM, McGregor PK. 2001. Corncrake Crex crex census estimates: A conservation application of vocal individuality. Animal Biodiversity and Conservation 24: 81-90.

Peres CA. 1993. Structure and spatial organization of an Amazonian terre firme forest primate community. Journal of Tropical Ecology 9: 259-276.

Robinson JG. 1981. Vocal regulation of inter- and intragroup spacing during boundary encounters in the titi monkey, $\mathrm{Cal}$ licebus moloch. Primates 22: 161-172.

Robinson JG, Wright P, Kinzey WG. 1987. Monogamous cebids and their relatives: intergroup calls and spacing. In: Smuts B, Cheney D, Seyfarth RM, Wrangham RW and Struhsaker TT, ed. Primate Societies. Chicago: University of Chicago Press, 44-53.

Rowe N, Martinez W. 2003. Callicebus sightings in Bolivia, Peru and Ecuador. Neotropical Primates. 11: 32-35.

Stallings J. 1994. Status and conservation of Paraguayan primates. MA thesis, University of Florida, USA.

Turner IM. 1996. Species loss in fragments of tropical rain forest: a review of the evidence. Jounal of Applied Ecology 33: 200-209.

van Roosmalen MGM, van Roosmalen T, Mittermeier RA. 2002. A taxonomic review of the titi monkeys, Callicebus Thomas 1903. Neotropical Primates. 10 (supplement): 152.

Wright PW. 1985. The costs and benefits of nocturnality for Aotus trivirgatus (the night monkeys). PhD Dissertation, City University of New York, USA.

Received: 20 December 2007

Accepted: 16 Januari 2008 